\title{
MOLECULAR ANALYSIS OF NSP4 CODING GENE OF PORCINE ROTAVIRUS IN BRAZIL
}

\author{
ANÁLISE MOLECULAR DO GENE CODIFICADOR DA NSP4 DE ROTAVÍRUS SUÍNOS \\ NO BRASIL
}

\author{
M. S. CUNHA ${ }^{1}$, P. E. BRANDÃO ${ }^{2}$, M. K. NISHIDA ${ }^{3}$, V. L. A. RUIZ ${ }^{4}$, F. GREGORI ${ }^{5 *}$
}

\begin{abstract}
RESUMO
A proteína não estrutural 4 (NSP4) desempenha diferentes funções na replicação e na morfogênese dos rotavírus, apresentando, ainda, uma atividade de enterotoxina, causando diarreia do tipo secretória. Um total de 11 sequências parciais de nucleotídeos do gene codificador da NSP4 de rotavírus suínos de criações brasileiras foram definidas como pertencentes ao grupo A. Comparando-se as sequências virais da área do peptídeo toxigênico, que compreende a porção entre os aminoácidos de 114 a 135, constatou-se uma única mutação pontual no aminoácido 135, sendo que duas amostras apresentaram alanina, e as demais, valina. A análise filogenética do gene demonstrou que todas as amostras pertencem ao genotipo E1, e que a identidade nucleotídica das amostras brasileiras variou de $92,4 \%$ a $100 \%$, enquanto que a identidade de aminoácidos, de $95,8 \%$ a $100 \%$. Apenas um resíduo (aa 138) sofreu seleção positiva enquanto que pelo menos outros 119 apresentam seleção negativa. Assim, esses dados mostram a ocorrência de um genotipo comum da NSP4 já descrito anteriormente em suínos, com uma baixa diversidade entre as amostras encontradas.
\end{abstract}

PALAVRAS-CHAVE: Genotipos. Proteína não-estrutural. Reoviridae.

\section{SUMMARY}

The non-structural protein 4 (NSP4) has different roles in rotaviral replication, morphogenesis, and enterotoxin-like activity causing secretory diarrhea. A total of 11 partial nucleotide sequences of NSP4 coding gene were defined from group A rotavirus circulating in Brazilian swine herds. On comparing the viral sequences of diarrheagenic peptide area (amino acid 114-135), there was a single point mutation at amino acid 135 presented by two strains with amino acid alanine, and valine in the others. The NSP4 gene phylogeny showed that all strains clustered into E1 genotype, and the nucleotide identity between Brazilian strains ranged from $92.4 \%$ and $100 \%$, while the putative amino acid identity, between $95.8 \%$ and $100 \%$. Only one site (138aa) was positively selected and at least 119 were negatively selected. As a conclusion, these data demonstrate the occurrence of a common NSP4 genotype described elsewhere in pigs and low diversity between the samples from the surveyed areas.

KEY-WORDS: Genotypes. Non-structural protein. Reoviridae.

\footnotetext{
${ }^{1}$ Instituto Biológico de São Paulo.

${ }^{2}$ Departamento de Medicina Veterinária Preventiva e Saúde Animal - VPS. Laboratório de Biologia Molecular Aplicada e Sorologia. Faculdade de Medicina Veterinária e Zootecnia da Universidade de São Paulo.

${ }^{3}$ Instituto Biológico de São Paulo.

${ }^{4}$ Departamento de Medicina Veterinária. Faculdade de Zootecnia e Engenharia de Alimentos da Universidade de São Paulo.

${ }^{5}$ Departamento de Medicina Veterinária Preventiva e Saúde Animal - VPS. Laboratório de Biologia Molecular Aplicada e Sorologia. Faculdade de Medicina Veterinária e Zootecnia da Universidade de São Paulo. Email.: fabiogregori@ gmail.com
} 


\section{INTRODUCTION}

Group A rotavirus (RV-A), members of the Reoviridae family, genus Rotavirus, are regarded as a major cause of gastroenteritis both in humans and animals worldwide (KAPIKIAN et al., 2001). The RV-A genome consists of 11 segments of double-stranded RNA, encoding six structural virus proteins (VP1-VP4, VP6 and VP7) and six non-structural proteins (NSP1-NSP6). The complete virus is a triple-layered particle, with VP4 and VP7 constituting the outer layer whose respective encoding genes are markers for $\mathrm{P}$ and $\mathrm{G}$ genotypes, respectively (KING et al., 2012). So far, 37 genotypes $P$ and $27 \mathrm{G}$ have been defined (DESSELBERGER, 2014). The inner capsid protein VP6 is important on host immunity and determines groups A-G, and more recently, a novel RV-H has been discovered (KING et al., 2012; MATTHIJNSSENS et al., 2012). Genotypes previously described in pigs include G1, G2, G3, G4, G5, G6, G11, and G12, usually associated with P[6], P[7], P[13], P[19], $\mathrm{P}$ [23], $\mathrm{P}[26]$, and $\mathrm{P}[27]$ (MATTHIJNSSENS et al., 2008b; TONIETTI et al., 2013).

The non-structural protein 4 (NSP4), encoded by gene segment 10, has multiple functions in RVs morphogenesis and pathogenesis. It has an enterotoxinlike activity (BALL et al., 1996) and has been identified as a viroporin (HYSER et al., 2012). The peptide 114135 is considered to trigger a signal transduction pathway as it increases intracellular calcium, leading to chloride secretion, and therefore secretory diarrhea, as it has been shown in mice (TIAN et al., 1995; BALL et al., 1996; HUANG et al., 2004). Changes within this region have been associated with alterations in the toxigenic activity of NSP4 and virulence of RVs (BALL et al., 1996; ZHANG et al., 1998). Anti-NSP4 antibodies demonstrated protection against viral- and NSP4induced diarrhea in mice, and together with VP4 and VP7, become an important pathway to rotavirus prevention and therapeutics (HOU et al., 2008).

So far, 15 NSP4 genotypes have been defined from RV-A samples infecting human and animal hosts (DESSELBERGER, 2014).

The aim of this investigation was to sequence and analyze a partial fragment of NSP4 gene of RV-A from different Brazilian pig herds to define their phylogenetic relations with other animal and human isolates described elsewhere.

\section{MATERIAL AND METHODS}

A total of 11 stool samples from pigs with diarrhea from three cities in São Paulo's State, Brazil, were collected in 2008 and screened with polyacrylamide gel electrophoresis (PAGE) (HERRING et al., 1982), ELISA (GREGORI et al., 2000), and characterized in $\mathrm{P}$ and $\mathrm{G}$ genotypes as previously described (GOUVEA et al., 1994a,b).

Feces suspensions (v/v; 50\%) were prepared with phosphate-buffered saline $0.01 \mathrm{M}, \mathrm{pH} 7.2$, clarified at $5000 \mathrm{~g} / 15 \mathrm{~min}$ at $4^{\circ} \mathrm{C}$, and the supernatants used in the assays.

Extraction of total RNA from the reference RVs strain (NCDV) and the supernatants of the field samples were carried out with TRIzol Reagent ${ }^{\mathrm{TM}}$ (Invitrogen, Carlsbad, CA, USA) according to the manufacturer's instructions.

For RT-PCR, $5.6 \mu \mathrm{L}$ of RNA solution was mixed with $1.4 \mu \mathrm{L}$ of DMSO and denatured at $95^{\circ} \mathrm{C}$ for 5 minutes and kept in ice. Then it was added to a solution of 1x First Strand Buffer (Invitrogen ${ }^{\mathrm{TM}}$ ), 1 $\mathrm{mM}$ of each dNTP, $10 \mathrm{mM}$ DTT, and $1 \mu \mathrm{M}$ of each primer targeting NSP4 coding gene (10BEG16 and 10END722) as described by Lee et al. (2000) and $200 \mathrm{U}$ of reverse transcriptase (Invitrogen ${ }^{\mathrm{TM}}$ ), to a $13 \mu \mathrm{L}$ final reaction volume. This mixture was then heated at $42^{\circ} \mathrm{C}$ for 1 hour and $70^{\circ} \mathrm{C}$ for $15 \mathrm{~min}$ at thermal cycler.

PCR amplification was carried out by adding $5 \mu \mathrm{L}$ of cDNA of the RT reaction in a mix containing 1x PCR Buffer (Invitrogen ${ }^{\mathrm{TM}}$ ), $0.2 \mathrm{mM}$ of each dNTP, $0.5 \mu \mathrm{M}$ of each primer (10BEG16 and 10END722), as described by Lee et al. (2000), $2 \mathrm{mM}$ of $\mathrm{MgCl}_{2}$, and $2.5 \mathrm{U}$ of Taq DNA Polymerase (Invitrogen ${ }^{\mathrm{TM}}$ ) and ultra-pure water for a final reaction volume of $50 \mu \mathrm{L}$. This mixture was heated at $94^{\circ} \mathrm{C}$ for $2 \mathrm{~min}$, followed by 30 cycles each at $95^{\circ} \mathrm{C}$ for $45 \mathrm{~s}, 49^{\circ} \mathrm{C}$ for $30 \mathrm{~s}, 72^{\circ} \mathrm{C}$ for $1.5 \mathrm{~min}$, and one cycle at $72^{\circ} \mathrm{C}$ for $10 \mathrm{~min}$. The products of the PCR were resolved on a $1.5 \%$ agarose gel stained with $0.5 \mu \mathrm{g} / \mathrm{mL}$ ethidium bromide.

Amplicons of $725 \mathrm{bp}$ in length were purified with Illustra GFX ${ }^{\mathrm{TM}}$ PCR DNA and Gel Band Purification Kit, according to the manufacturer's instructions (GE Healthcare) and submitted to bidirectional sequencing with BigDye 3.1 ${ }^{\mathrm{TM}}$ (Applied Biosystems, Carlsbad, CA, USA) according to the manufacturer's instructions. The reaction products of the sequencing reactions were resolved in the automatic sequencer ABI-377 TM (Applied Biosystems, Carlsbad, CA, USA).

Nucleotide sequences obtained in this study (nt 66 to nt 566, using as reference Gottfried Strain accession number GU199490) (Table 1) were aligned among them and with representative strains belonging to different NSP4 genotypes according to Matthijnssens et al. (2008a) using Bioedit 7.0.5.3 software (HALL, 1999) and Clustal W 1.83 (THOMPSON et al., 1994) downloaded from the NCBI GenBank database. The strains used were (genotype/accession number/host/strain):
a) E1/GU199490/Swine/Gottfried;
b) E1/DQ494398/Bovine/KJ75;
c) E1/AF144799/Swine/A411;
d) E1/D88831/Swine/OSU;
e) E1/X69485/Swine/YM;
f) E1/U59109/Human/M37;
g) E2/AF144805/Bovine/B223;
h) E3/AF144806/Canine/CU 1;
i) E4/AB065285/Avian/Ty 1;
j) E5/AF533535/Lapine/160 01;
k) E6/DQ490560/Human/RV176 06;
1) E7/U96337/Murine/EC;
m) E8/EF442742/Canine/RV52 96;
n) E9/DQ534017/Swine/CMP034;
o) E10/FJ169862/Avian/02V0002G3; and
p) E12/FJ347120/Bovine/Arg B383. 
Table 1 - P and G genotypes and accession numbers of partial NSP4 sequences RVs from piglet samples in São Paulo State, Brazil. Gaps indicate genotypes that were not defined.

\begin{tabular}{cccc}
\hline Strain & Genotype P & Genotype G & NSP4 Accession number \\
\hline PORV1 & P[6] & G[11] & HQ840943 \\
\hline PORV2 & P[6] & G[11] & HQ840944 \\
\hline PORV3 & P[6] & G[11] & HQ840945 \\
\hline PORV4 & P[6] & G[11] & HQ840946 \\
\hline PORV5 & - & - & HQ840948 \\
\hline PORV6 & - & G[10] & HQ840949 \\
\hline PORV7 & P[7] & - & HQ840952 \\
\hline PORV8 & P[6] & - & HQ840950 \\
\hline PORV9 & P[7] & - & HQ840953 \\
\hline PORV10 & P[7] & G[10] & HQ840954 \\
\hline PORV11 & - & G[10] & \\
\hline
\end{tabular}

The nucleotide and amino acid similarities were calculated using Bioedit v. 7.0.5.3 software (HALL, 1999). The phylogenetic tree from nucleotide sequences was built using MEGA software version 4 (TAMURA et al., 2007) based on Neighbor-joining method using Maximum Composite Likelihood (1,000 bootstrap trials).

The codon sites from an alignment comprising 83 porcine rotaviral NSP4 encoding gene were retrieved from Genbank and analysed using HyPhy software available at Datamonkey web-server (http://www.datamonkey.org) in order to detect specific positive selection (KOSAKOVSKY POND \& FROST, 2005). From these, 10 presented sequence duplicity and were automatically discarded by the software before the screening for recombinants using GARD (Genetic Algorithms for Recombination Detection). After, the sites were evaluated with SLAC (Single Likelihood Ancestor Counting), MEME (Mixed Effects Model of Episodic Diversifying Selection), and FUBAR (Fast Unconstrained Bayesian Approximation) methods. The HKY85 nucleotide substitution model on a Neighborjoining tree was adopted both in SLAC and MEME, with a $P$ value $<0.1$, and for FUBAR a posterior probability $>0.9$, using the value of difference between nonsynonymous and synonymous substitutions $(d N-d S)$ as measure of selective pressure.

\section{RESULTS}

For the 11 samples, a common fragment of 501 nt (nt 66 to nt 566, using as reference Gottfried Strain accession number GU199490) from RVs NSP4-coding gene was investigated. The strain identification, $\mathrm{P}$ and $\mathrm{G}$ genotypes, and respective NSP4 gene accession numbers are shown in Table 1 . The Genbank accession numbers for the NSP4 partial gene sequences of porcine rotaviruses determined in this study are: HQ840943, HQ840944, HQ840945, HQ840946, HQ840947, HQ840948, HQ840949, HQ840950, HQ840952, HQ840953, HQ840954.

Nucleotide identity between samples tested in this study ranged from $92.4 \%$ to $100 \%$ while amino acid ranged from $95.8 \%$ to $100 \%$. The comparison of NSP4 genes sequenced in this study with other strains classified as genotype E1 from GenBank revealed a nucleotide identity ranging from $94.4 \%$ (strain PORV6 with porcine strains Gottfried and OSU) to $84.1 \%$ (strain PORV9 with human strain EF672589) and amino acid identity ranging from $98.8 \%$ (strains PORV1; PORV2; PORV3; PORV4; PORV6; PORV7; and PORV11 with Venezuelan porcine strain AF165219) to 89.4\% (strain PORV5 with human strain EF672589).

Deduced amino acids of the sequences generated herein revealed a moderate variation among the strains (Figure 1). Moreover, considering the toxigenic peptide (amino acid 114-135) it was shown that there was a single point mutation on aa 135 presented as alanine in two RV strains and as valine in the other strains. In addition, six other amino acid changes at residues 136 (valine, alanine and serine), 137 (arginine and glycine), 139 (isoleucine and valine), 154 (arginine and lysine), 161 (serine and asparagine) and 174 (serine and proline) were found.

The phylogenetic tree (Figure 2) depicts that the strains of the present study clustered with E1 genotype representatives, while the others segregated in separate clusters with a resolved genealogy, according to its genotypes. 


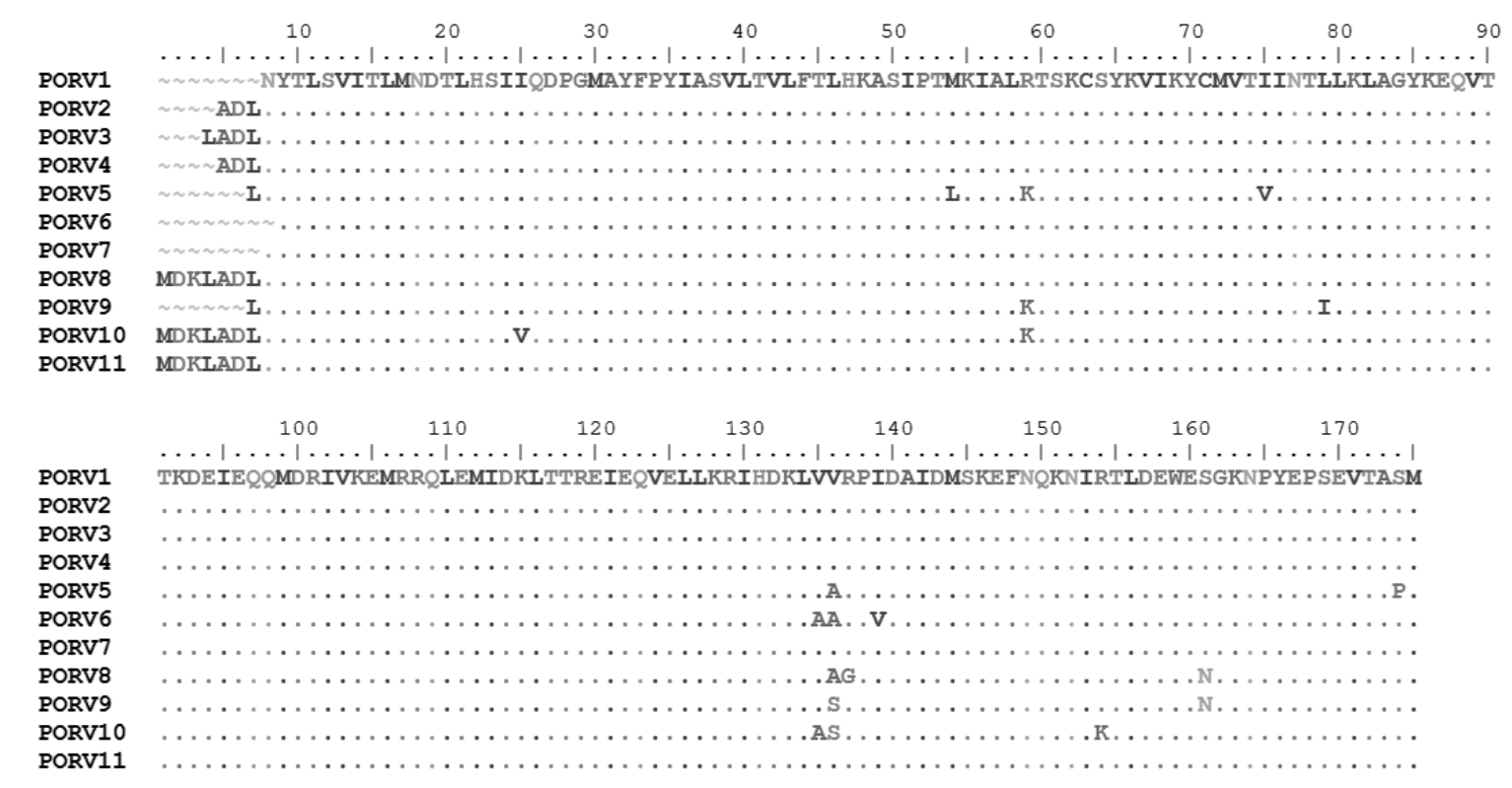

Figure 1 - Section of the alignment of the deduced 175 amino acids of the NSP4-coding gene from rotavirus detected in porcine stool samples from Brazilian herds.

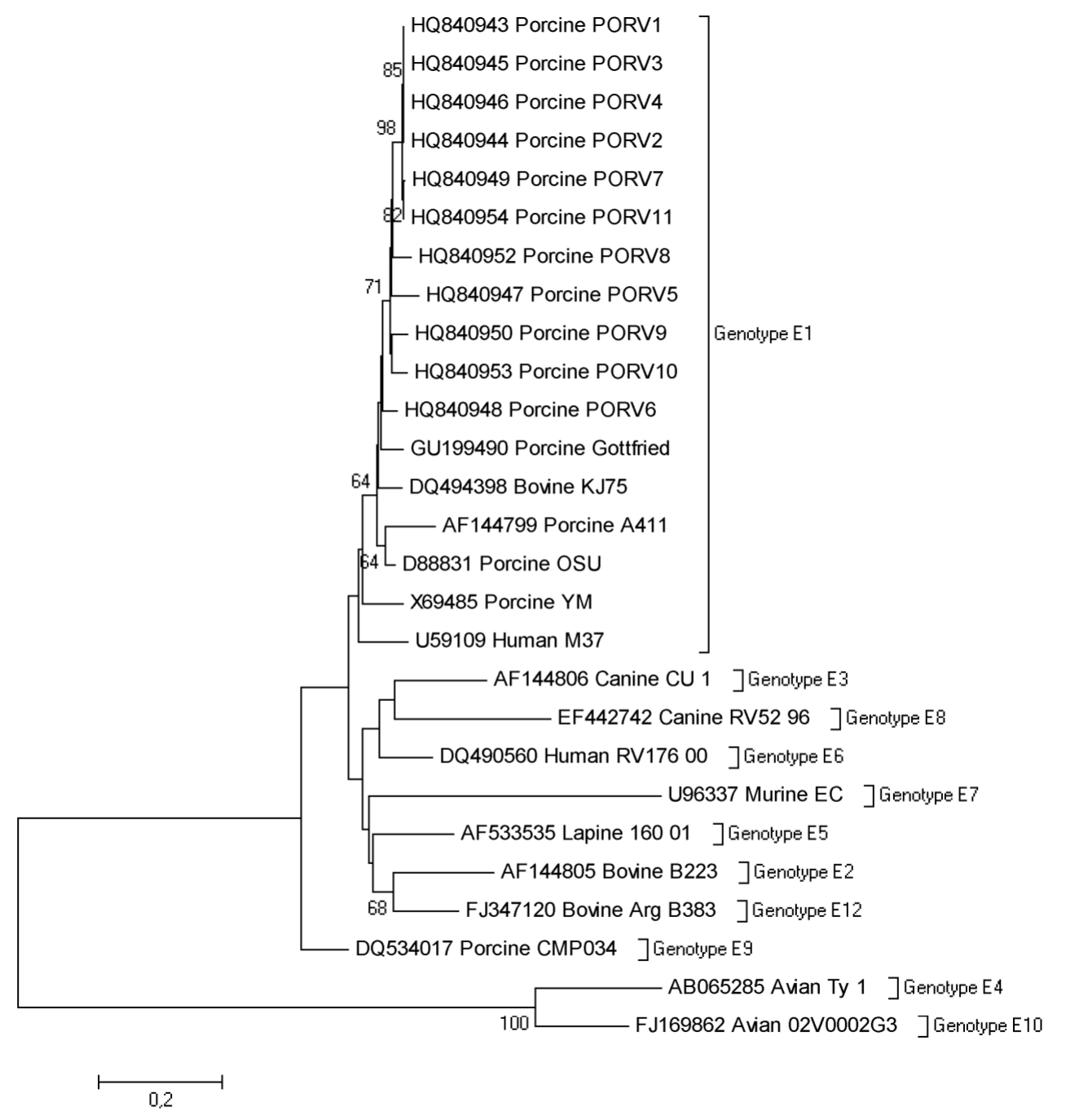

Figure 2 - Unrooted neighbor-joining tree for a stretch of 501 nucleotides of the NSP4-coding gene, showing the proposed E genotypes. Taxa designated as "PORV (1 to 11)" are related to the Brazilian field strains from the present study; numbers at each node are the bootstrap values greater than $50 \%$ obtained with 1,000 replicates. 
There SLAC analysis indicated only one positively selected site, codon 138 , presenting normalized $\mathrm{dN}-\mathrm{dS}$ of $1.005(P=0.092)$ and 119 negatively selected (119/175 codons). According to MEME method, 3 sites presented evidence of episodic diversifying selection, including the codon 138 ( $P=$ 0.0026) whereas the FUBAR have not found sites with evidence of pervasive diversifying selection and 154 sites with evidence of pervasive purifying selection, but not at the codon 138. The most common amino acid residue found at the position 138 was proline $(73,97 \%)$, followed by serine $(13,69 \%)$, asparagine $(9,58 \%)$, and threonine $(2,73 \%)$.

\section{DISCUSSION}

Among bovine NSP4 amino acid sequences, most of the divergence was observed in the VP4binding domain (aa 112-146) and in the double-layered particle-binding region (aa 161-175) (MATTION et al., 1994; MALIK et al., 2014). Porcine strains of the present study showed low degree of polymorphism in both regions, with four and two mutations respectively, as shown in Figure 1.

Strains PORV6 and PORV10 presented amino acid residue alanine at position 135 , while the others presented amino acid valine. By comparisons of NSP4 sequences, Zhang et al. (1998) suggested that changes between amino acids 131 and 140 are important for viral pathogenesis, and demonstrated that a change from amino acid valine to alanine in the NSP4 protein at this position was important in OSU attenuated strains, as it was associated with loss of the ability of inducing diarrhea in mice, which was also observed in a piglet model with virulent and tissue cultureattenuated human RVs Wa strains (WARD et al., 1996). On the other hand, Kirkwood et al. (1996) found isoleucine at position 135 in symptomatic children, as well as did Mascarenhas et al. (2007).

Tyrosine residue at position 131 of NSP4 coding gene has been postulated to be critical for the diarrheagenic activity of the toxic peptide (BALL et al. 1996), but histidine was also found in diarrheic young children (CUNLIFFE et al., 1997; MASCARENHAS et al., 2007). Sequence analysis from porcine strains revealed amino acids serine, alanine and histidine at residue 131 (CIARLET et al., 2000; STEYER et al., 2007; MATTHIJNSSENS et al., 2010). In the present study, all strains showed histidine, as shown in Figure 1. Therefore, the enterotoxin domain (aa 114-135) is conserved among them, except for one mutation at aa 135 .

Even though nucleotide and amino acid polymorphisms were found both at the toxigenic peptide, VP4-binding domain and in the doublelayered particle-binding region, as observed in Figure 1 , it was not possible to speculate on the significance of these changes for the virulence of the RV strains since all the animals studied presented diarrhea. In other studies, this correlation between virulent and attenuated strains was not observed (WARD et al., 1997; ANGEL et al., 1998), showing the possibility that virus attenuation can occur by several mechanisms, including mutations in other viral proteins. Besides that, the extreme $\mathrm{C}$ terminus, including aa methionine at position 175 was shown to be important for double-layered particle (DLP)-binding activity (TAYLOR et al., 1992). As shown in Figure 1, all the porcine strains presented methionine at this site.

Moreover, the site specific analysis under 2 different methods (SLAC and MEME) pointed out only one site (codon 138) with genetic positive pressure, located at the VP4 binding domain (MATTION et al., 1994), while no evidence of genetic recombination was found by GARD method and at least 119 sites were negatively selected according to SLAC. When performing molecular analysis of bovine NSP4 enterotoxin gene, Malik et al. (2014) have also found only one position (154) positively selected, and concluded that the strong negative selection that undergo in this gene suggests the role of maintenance of biological functional domains while deleterious mutations are being removed, as found in other nonstructural proteins, like the NSP2 encoding gene (DONKER \& KIRKWOOD, 2012).

This study revealed the occurrence of genotypes G10 and G11 in association with $\mathrm{P}[6]$ or $\mathrm{P}[7]$ in the swine population. G10 genotype has been widely detected in bovine rotaviruses in Brazil (ALFIERI et al., 2004) and other countries (FALCONE et al., 1999; GARAICOECHEA et al., 2006; HOWE et al., 2008), and also in humans (URASAWA et al., 1993; RAMANI et al., 2009). A study in Thailand also revealed this genotype in pigs (PONGSUWANNA et al., 1996).

G11 rotaviruses were first detected in pigs in Mexico and Venezuela (RUIZ et al., 1988; CIARLET et al., 1994; ROSEN et al., 1994) and are believed to be circulating in this population, although in low numbers. In subsequent years, no additional G11 strains were detected in the same or nearby pig farms, but in the last decade, several reports have described the isolation of G11 RVs strains from humans (MATTHIJNSSENS et al., 2010). These authors also showed that multiple reassortment events have occurred between porcine or human G11 rotaviruses and co-circulating human Wa-like RVs strains.

The phylogenetic tree (Figure 2) showed that the circulating Brazilian RVs strains belong to E1 genotype, also reported elsewhere in humans, swine, equine, and bovine (MATTHIJNSSENS et al., 2008a), reinforcing the association between E1 genotype and pig RVs previously described. Although evidences for independent segregation of the VP6- and NSP4encoding genes have been described in porcine RV-A (ITURRIZA-GÓMARA, 2002; GHOSH et al., 2006), considering the limited number of surveyed samples and occurrence of undefined $P$ and $G$ genotypes, it was not possible to observe this pattern among Brazilian samples.

Interspecies transmission of rotaviruses may occur in natural and experimental conditions (MARTELLA et al., 2010). The introduction of a new human-animal reassortant $\mathrm{RVs}$ strain into the human population could have an impact on the spread of rotavirus disease and also on prevention measures (STEYER et al., 2008). This study also revealed (data 
not shown) that strain PORV6 had 96,4\% amino acid identity with Brazilian strain NB-150, a human strain previously isolated by Mascarenhas et al. (2007) from a newborn with diarrhea who lived in the outskirts of Belém, State of Pará, Brazil, that reinforce the hypothesis that interspecies transmission may occur naturally, without loss of virulence (VARGHESE et al., 2004).

There are numerous examples of RVs interspecies transmission, but there are few documented evidences in which whether the transmission event has involved the whole genome (PALOMBO, 2002). In fact, pigs may serve as a reservoir of RVs for humans, as described by several authors in different countries, such as India, Ecuador and Hungary (BANYAI et al., 2004; VARGHESE et al., 2004; BANYAI et al., 2009). It has been proposed that human RVs Wa-like strains and swine strains have a common origin (MATTHIJNSSENS et al., 2008b), and, recently, a new virus isolated from pigs was closely related to a novel group of human rotaviruses (WAKUDA et al., 2011).

\section{CONCLUSIONS}

As a conclusion, NSP4 genes of porcine RVs isolated in Brazil during 2008 had only a moderate polymorphism and belonged all to $\mathrm{E} 1$, in an extent previously unknown in this country.

\section{ACKNOWLEDGMENTS}

This work was supported by grant $n^{\circ}$ 577884/2008-5 from National Council for Scientific and Technological Development (CNPq) and Brazilian Ministry of Agriculture, Livestock and Food Supply (MAPA).

\section{REFERENCES}

ALFIERI, A. F.; ALFIERI, A. A.; BARREIROS, M. A.; LEITE, J. P.; RICHTZENHAIN, L. J. G and P genotypes of group A rotavirus strains circulating in calves in Brazil, 1996-1999. Veterinary Microbiology, v.99, n.3-4, p.167-173, 2004.

ANGEL, J.; TANG, B.; FENG, N.; GREENBERG, H. B.; BASS, D. Studies of the role for NSP4 in the pathogenesis of homologous murine rotavirus diarrhea. Journal of Infectious Diseases, v.177, n.2, p.455-458, 1998.

BALL, J. M.; TIAN, P.; ZENG, C. Q.; MORRIS, A. P.; ESTES, M. K. Age-dependent diarrhea induced by a rotaviral nonstructural glycoprotein. Science, v.272, n.5258, p.101-104, 1996.

BANYAI, K.; ESONA, M. D.; KERIN, T. K.; HULL, J. J.; MIJATOVIC, S.; VÁSCONEZ, N.; TORRES, C.; DE FILIPPIS, A. M.; FOYTICH, K. R.; GENTSCH, J. R. Molecular characterization of a rare, human-porcine reassortant rotavirus strain, G11P[6], from Ecuador. Archives of Virology, v.154, n.11, p.1823-1829, 2009.
BANYAI, K.; MARTELLA, V.; JAKAB, F.; MELEGH, B.; SZÜCS, G. Sequencing and phylogenetic analysis of human genotype $\mathrm{P}[6]$ rotavirus strains detected in Hungary provides evidence for genetic heterogeneity within the P[6] VP4 gene. Journal of Clinical Microbiology, v.42, n.9, p.4338-4343, 2004.

CIARLET, M.; HIDALGO, M.; GORZIGLIA, M.; LIPRANDI, F. Characterization of neutralization epitopes on the VP7 surface protein of serotype G11 porcine rotaviruses. The Journal of General Virology, v.75, n.8, p.1867-1873, 1994.

CIARLET, M.; LIPRANDI, F.; CONNER, M. E.; ESTES, M. K. Species specificity and interspecies relatedness of NSP4 genetic groups by comparative NSP4 sequence analyses of animal rotaviruses. Archives of Virology, v.145, n.2, p.371-383, 2000.

CUNLIFFE, N. A.; WOODS, P. A.; LEITE, J. P. G.; DAS, B. K.; RAMACHANDRAN, M.; BHAN, M. K.; HART, C. A.; GLASS, R. I.; GENTSCH, J. R. Sequence analysis of NSP4 gene of human rotavirus allows classification into two main genetic groups. Journal of Medical Virology, v.53, n.1, p.41-50, 1997.

DESSELBERGER, U. Rotaviruses. Virus Research, v.190, p.75-96, 2014.

DONKER, N. C.; KIRKWOOD, C. D. Selection and evolutionary analysis in the nonstructural protein NSP2 of rotavirus A. Infection, Genetics and Evolution, v.12, n.7, p.1355-1361, 2012.

FALCONE, E.; TARANTINO, M.; DI TRANI, L.; CORDIOLI, P.; LAVAZZA, A.; TOLLIS, M. Determination of bovine rotavirus $G$ and $P$ serotypes in Italy by PCR. Journal of Clinical Microbiology, v.37, n.12, p.3879-3882, 1999.

GARAICOECHEA, L.; BOK, K.; JONES, L. R.; COMBESSIES, G.; ODEÓN, A.; FERNANDEZ, F.; PARREÑO, V. Molecular characterization of bovine rotavirus circulating in beef and dairy herds in Argentina during a 10-year period (1994-2003). Veterinary Microbiology, v.118, n.1-2, p.1-11, 2006.

GHOSH, S.; VARGHESE, V.; SAMAJDAR, S.; BHATTACHARYA, S. K.; KOBAYASHI, N.; NAIK, T. N. Molecular characterization of a porcine group A rotavirus strain with G12 genotype specificity. Archives of Virology, v.151, n.7, p.1329-1344, 2006.

GOUVEA, V.; SANTOS, N.; TIMENETSKY, M. C. Identification of bovine and porcine rotavirus $G$ types by PCR. Journal of Clinical Microbiology, v.32, n.5, 1338-1340, 1994a.

GOUVEA, V.; SANTOS, N.; TIMENETSKY, M. C. VP4 typing of bovine and porcine group A rotaviruses by PCR. Journal of Clinical Microbiology, v.32, n.5, 1333-1337, 1994b. 
GREGORI, F.; BRANDÃO, P. E.; ROSALES, C. A. R.; CORTEZ, A.; HEINEMANN, M. B.; RICHTZENHAIN, L. J.; JEREZ, J. A. Desenvolvimento de um método de ELISA para a detecção de rotavírus a partir de material fecal. Arquivos do Instituto Biológico, v.67, n.2, p.191-194, 2000.

HALL, T. A. BioEdit: a user-friendly biological sequence alignment editor and analysis program for Windows 95/98/NT. Nucleic Acids Symposium Series, v.41, n.1, p.95-98, 1999.

HERRING, A. J.; INGLIS, N. F.; OJEH, C. K.; SNODGRASS, D. R.; MENZIES, J. D. Rapid diagnosis of rotavirus infection by direct detection of viral nucleic acid in silver-stained polyacrylamide gels. Journal of Clinical Microbiology, v.16, n.3, p.473-477, 1982.

HOU, Z.; HUANG, Y.; HUAN, Y.; PANG, W.; MENG, M.; WANG, P.; YANG, M.; JIANG, L.; CAO, X.; WU, K. K. Anti-NSP4 antibody can block rotavirus-induced diarrhea in mice. Journal of Pediatric Gastroenterology and Nutrition, v.46, n.4, p.376-385, 2008.

HOWE, L.; SUGIARTO, H.; SQUIRES, R. A. Use of polymerase chain reaction for the differentiation of group A bovine rotavirus G6, G8, and G10 genotypes in the north island of New Zealand. New Zealand Veterinary Journal, v.56, n.5, p.218-221, 2008.

HUANG, H.; SCHROEDER, F.; ESTES, M. K.; MCPHERSON, T.; BALL, J. M. Interaction(s) of rotavirus non-structural protein 4 (NSP4) C- terminal peptides with model membranes. The Biochemical Journal, v.380, n.3, p.723-733, 2004.

HYSER, J. M.; UTAMA, B.; CRAWFORD, S. E.; ESTES, M. K. Genetic divergence of rotavirus nonstructural protein 4 results in distinct serogroupspecific viroporin activity and intracellular punctate structure morphologies. Journal of Virology, v.86, n.9, p.4921-34, 2012.

ITURRIZA-GÓMARA, M.; WONG, C.; BLOME, S.; DESSELBERGER, U.; GRAY J. Molecular characterization of VP6 genes of human rotavirus isolates: correlation of genogroups with subgroups and evidence of independent segregation. Journal of Virology, v.76, n.13, p.6596-6601, 2002.

KAPIKIAN, A. Z.; HOSHINO, Y.; CHANOCK, R. M. Rotaviruses. In: KNIPE, D. M.; HOWLEY, P. M.; GRIFFIN, D. E.; LAMB, R. A.; MARTIN, M. A.; ROIZMAN, B.; STRAUS, S. E. (Eds). Fields Virology, 4.ed. Philadelphia:Lippincott, Williams \& Wilkins, 2001, p.1787-1833.

KING, A. M. Q.; ADAMS, M. J.; CARSTENS, E. B.; LEFKOWITZ, E. J. Virus taxonomy: classification and nomenclature of viruses: Ninth Report of the International Committee on Taxonomy of Viruses. San Diego: Elsevier Academic Press, 2012, p.603-613.
KIRKWOOD, C. D.; COULSON, B. S.; BISHOP, R. F. G3P2 rotaviruses causing diarrheal disease in neonates differ in VP4, VP7 and NSP4 sequence from G3P2 strains causing asymptomatic neonatal infection. Archives of Virology, v.141, n.9, p.1661-1676, 1996.

KOSAKOVSKY POND, S. L.; FROST, S. D. W. Datamonkey: rapid detection of selective pressure on individual sites of codon alignments. Bioinformatics, v.21, n.10, p. 2531-2533, 2005.

LEE, C. N.; WANG, Y. L.; KAO, C. L.; ZAO, C. L.; LEE, C. Y.; CHEN, H. N. NSP4 gene analysis of Rotavirus recovered from infected children with and without diarrhea. Journal of Clinical Microbiology, v.38, n.12, p.4471-4477, 2000.

MALIK, Y. S.; KUMAR, N.; SHARMA, K.; GHOSH, S.; BÁNYAI, K.; BALASUBRAMANIAN, G.; KOBAYASHI, N.; MATTHIJNSSENS, J. Molecular analysis of non structural rotavirus group A enterotoxin gene of bovine origin from India. Infection, Genetics and Evolution, v.25, p.20-27, 2014.

MARTELLA, V.; BÁNYAI, K.; MATTHIJNSSENS, J.; BUONAVOGLIA, C.; CIARLET, M. Zoonotic aspects of rotaviruses. Veterinary Microbiology, v.140, n.3-4, p.246-255, 2010.

MASCARENHAS, J. D.; LEITE, J. P.; LIMA, J. C.; HEINEMANN, M. B.; OLIVEIRA, D. S.; ARAÚJO, I. T.; SOARES, L. S.; GUSMÃO, R. H.; GABBAY, Y. B.; LINHARES, A. C. Detection of a neonatal human rotavirus strain with VP4 and NSP4 genes of porcine origin. Journal of Medical Microbiology, v.56, n.4, p.524-532, 2007.

MATTHIJNSSENS, J.; CIARLET, M.; HEIMAN, E.; ARIJS, I.; DELBEKE, T.; MCDONALD, S. M.; PALOMBO, E. A.; ITURRIZA-GÓMARA, M.; MAES, P.; PATTON, J. T.; RAHMAN, M.; VAN RANST, M. Full genome-based classification of rotaviruses reveals a common origin between human Wa-Like and porcine rotavirus strains and human DS1-like and bovine rotavirus strains. Journal of Virology, v.82, n.7, p.3204-3219, 2008a.

MATTHIJNSSENS, J.; CIARLET, M.; RAHMAN, M.; ATTOUI, H.; BÁNYAI, K.; ESTES, M. K.; GENTSCH, J. R.; ITURRIZA-GÓMARA, M.; KIRKWOOD, C. D.; MARTELLA, V.; MERTENS, P. P.; NAKAGOMI, O.; PATTON, J. T.; RUGGERI, F. M.; SAIF, L. J.; SANTOS, N.; STEYER, A.; TANIGUCHI, K.; DESSELBERGER, U.; VAN RANST, M. Recommendations for the classification of group A rotaviruses using all 11 genomic RNA segments. Archives of Virology, v.153, n.8, p.1621-1629, $2008 \mathrm{~b}$.

MATTHIJNSSENS, J.; OTTO, P. H.; CIARLET, M.; DESSELBERGER, U.; VAN RANST, M.; JOHNE, R. VP6-sequence-based cutoff values as a criterion for rotavirus species demarcation. Archives of Virology, v.157, n.6, p.1177-1182, 2012. 
MATTHIJNSSENS, J.; RAHMAN, M.; CIARLET, M.; ZELLER, M.; HEYLEN, E.; NAKAGOMI, T.; UCHIDA, R.; HASSAN, Z.; AZIM, T.; NAKAGOMI, O.; VAN RANST, M. Reassortment of human rotavirus gene segments into G11 rotavirus strains. Emerging Infectious Diseases, v.16, n.4, p.625-630, 2010.

MATTION, N. M.; COHEN, J.; ESTES, M. K. The Rotavirus Proteins. In: KAPIKIAN, A.Z. (Ed). Viral Infections of the Gastrointestinal tract, 2.ed. New York:Marcel Dekker, 1994, p.169-249.

PALOMBO, E. A. Genetic analysis of Group A rotaviruses, evidence for interspecies transmission of rotavirus genes. Virus Genes, v.24, n.1, p.11-20, 2002.

PONGSUWANNA, Y.; TANIGUCHI, K.; CHIWAKUL, M.; URASAWA, T.; WAKASUGI, F.; JAYAVASU, C.; URASAWA, S. Serological and genomic characterization of porcine rotaviruses in Thailand: detection of a G10 porcine rotavirus. Journal of Clinical Microbiology, v.34, n.5, p.1050-1057, 1996.

RAMANI, S.; ITURRIZA-GOMARA, M.; JANA, A. K.; KURUVILLA, K. A.; GRAY, J. J.; BROWN, D. W.; KANG, G. Whole genome characterization of reassortant G10P[11] strain (N155) from a neonate with symptomatic rotavirus infection: identification of genes of human and animal rotavirus origin. Journal of Clinical Virology, v.45, n.3, p.237-244, 2009.

ROSEN, B. I.; PARWANI, A. V.; LOPEZ, S.; FLORES, J.; SAIF, L. J. Serotypic differentiation of rotaviruses in field samples from diarrheic pigs by using nucleic acid probes specific for porcine VP4 and human and porcine VP7 genes. Journal of Clinical Microbiology, v.32, n.2, p.311-317, 1994.

RUIZ, A. M.; LOPEZ, I. V.; LOPEZ, S.; ESPEJO, R. T.; ARIAS, C. F. Molecular and antigenic characterization of porcine rotavirus YM, a possible new rotavirus serotype. Journal of Virology, v.62, n.11, p.4331-4336, 1988.

STEYER, A.; POLJSAK-PRIJATELJ, M.; BARLICMAGANJA, D.; JAMNIKAR, U.; MIJOVSKI, J. Z.; MARIN, J. Molecular characterization of a new porcine rotavirus $\mathrm{P}$ genotype found in an asymptomatic pig in Slovenia. Virology, v.359, n.2, p.275-282, 2007.

STEYER, A.; POLJSAK-PRIJATELJ, M.; BARLICMAGANJA, D.; MARIN, J. Human, porcine and bovine rotaviruses in Slovenia, evidence of interspecies transmission and genome reassortment. Journal of General Virology, v.89, n.7, p.1690-1698, 2008.

TAMURA, K.; DUDLEY, J.; NEI, M.; KUMAR, S. MEGA4: Molecular Evolutionary Genetics Analysis (MEGA) software version 4.0. Molecular Biology and Evolution, v.24, n.8, p.1596-1599, 2007.

TAYLOR, J. A.; MEYER, J. C.; LEGGE, M. A.; O'BRIEN, J. A.; STREET, J. E.; LORD, V. J.; BERGMANN, C. C.; BELLAMY, A. R. Transient expression and mutational analysis of the rotavirus intracellular receptor: the $\mathrm{C}$-terminal methionine residue is essential for ligand binding. Journal of Virology, v.66, n.6, p.3566-3572, 1992.

THOMPSON, J. D.; HIGGINS, D. G.; GIBSON, T. J. CLUSTAL, W: Improving the sensitivity of progressive multiple sequence alignment through sequence weighting, position-specific gap penalties and weight matrix choice. Nucleic Acids Research, v.22, n.22, p.4673-4680, 1994.

TIAN, P.; ESTES, M. K.; HU, Y.; BALL, J. M.; ZENG, C. Q.; SHILLING, W. P. The rotavirus nonstructural glycoprotein NSP4 mobilizes $\mathrm{Ca}^{2+}$ from the endoplasmic reticulum. Journal of Virology, v.69, n.9, p.5763-5772, 1995.

TONIETTI, P. O.; HORA, A. S.; SILVA, F. D. F.; RUIZ, V. L. A.; GREGORI, F. Phylogenetic analyses of the VP4 and VP7 genes of porcine group A rotaviruses in Sao Paulo State, Brazil: first identification of G5P[23] in piglets. Journal of Clinical Microbiology, v.51, n.8, p.2750-2753, 2013.

URASAWA, T.; TANIGUCHI, K.; KOBAYASHI, N.; MISE, K.; HASEGAWA, A.; YAMAZI, Y.; URASAWA, S. Nucleotide sequence of VP4 and VP7 genes of a unique human rotavirus strain Mc35 with subgroup I and serotype 10 specificity. Virology, v.195, n.2, p.766-771, 1993.

VARGHESE, V.; DAS, S.; SINGH, N. B.; KOJIMA, K.; BHATTACHARYA, S. K.; KRISHNAN, T.; KOBAYASHI, N.; NAIK, T. N. Molecular characterization of a human rotavirus reveals porcine characteristics in most of the genes including VP6 and NSP4. Archives of Virology, v.149, n.1, p.155-172, 2004.

WAKUDA, M.; IDE, T.; SASAKI, J.; KOMOTO, S.; ISHII, J.; SANEKATA, T.; TANIGUCHI, K. Porcine rotavirus closely related to novel group of human rotaviruses. Emerging Infectious Diseases, v.17, n.8, p.1491-1493, 2011.

WARD, R. L.; MASON, B. B.; BERNSTEIN, D. I.; SANDER, D. S.; SMITH, V. E.; ZANDLE, G. A.; RAPPAPORT, R. S. Attenuation of a human rotavirus vaccine candidate did not correlate with mutations in the NSP4 protein gene. Journal of Virology, v.71, n.8, p.6267-6270, 1997.

WARD, L. A.; ROSEN, B. I.; YUAN, L.; SAIF, L. J. Pathogenesis of an attenuated and a virulent strain of group A human rotavirus in neonatal gnotobiotic pigs. The Journal of General Virology, v.77, n.7, 1431-1441, 1996.

ZHANG, M.; ZENG, C. Q.; DONG, Y.; BALL, J. M.; SAIF, L. J.; MORRIS, A. P.; ESTES, M.K. Mutations in rotavirus nonstructural glycoprotein NSP4 are associated with altered virus virulence. Journal of Virology, v.72, n.5 p.3666-3672, 1998. 